\title{
Medicinal plants used by the Tamang community in the Makawanpur district of central Nepal
}

\author{
Dol Raj Luitel ${ }^{1 *}$, Maan B Rokaya ${ }^{2,3^{*}}$, Binu Timsina ${ }^{3,4}$ and Zuzana Münzbergová2,4
}

\begin{abstract}
Background: We can conserve cultural heritage and gain extensive knowledge of plant species with pharmacological potential to cure simple to life-threatening diseases by studying the use of plants in indigenous communities. Therefore, it is important to conduct ethnobotanical studies in indigenous communities and to validate the reported uses of plants by comparing ethnobotanical studies with phytochemical and pharmacological studies.

Materials and methods: This study was conducted in a Tamang community dwelling in the Makawanpur district of central Nepal. We used semi-structured and structured questionnaires during interviews to collect information. We compared use reports with available phytochemical and pharmacological studies for validation.

Results: A total of 161 plant species belonging to 86 families and 144 genera to cure 89 human ailments were documented. Although 68 plant species were cited as medicinal in previous studies, 55 different uses described by the Tamang people were not found in any of the compared studies. Traditional uses for 60 plant species were consistent with pharmacological and phytochemical studies.

Conclusions: The Tamang people in Makawanpur are rich in ethnopharmacological understanding. The present study highlights important medicinal plant species by validating their traditional uses. Different plant species can improve local economies through proper harvesting, adequate management and development of modern techniques to maximize their use.
\end{abstract}

Keywords: Makawanpur district, Medicinal plants, Pharmacology, Phytochemistry, Tamang community

\section{Background}

Plants have been used for human benefit from time immemorial [1]. In the developing world, $70-80 \%$ of the population relies on plants for primary health care [2]. The use of plants as medicine is slowly increasing in the developed world [3] because they have minor or no side effects [4]. Although there is wide use of herbal medicine, traditional knowledge of the use of medicinal plants is influenced by rapid urbanization, migration, climate change, and the increasing number of modern healthcare systems throughout the world, including in Nepal [5-10]. The traditional use of plants by indigenous communities reflects the cultural aspects as well as biodynamic elements that have

\footnotetext{
* Correspondence: luiteldr2@gmail.com; rokayamaan@gmail.com 'Department of Plant Resources Office, Ministry of Forest and Soil Conservation, Thapathali, Kathmandu, Nepal

${ }^{2}$ Institute of Botany, Academy of Sciences of the Czech Republic, Zamek 1, Průhonice 25243, Czech Republic

Full list of author information is available at the end of the article
}

immense pharmacological potential to cure many diseases $[11,12]$. The documentation of traditional knowledge aids in the preservation of indigenous culture, identifies threatened species and contributes to the conservation and management of plant diversity [13,14]. The cultural and biological diversity of Nepal offers immense opportunities for ethnobotanical studies [7,15-17]. In Nepali traditional medicine, more than 2300 plant species [18] are used by 125 caste/ethnic communities speaking approximately 123 different languages [19].

In addition to documenting the traditional knowledge related to medicinal plants, scientific validation of traditional medicinal plants has been an important path of recent research [20]. Validation is performed by in-vitro [21-23] or in-vivo experiments [24-26] or by isolation of important secondary metabolites that are useful for treating particular types of diseases or disorders [21,27]. In addition, previously published studies can also aid in

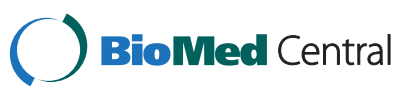


establishing links between traditional uses and modern scientific knowledge [20,28-31]. The practice of seeking evidence helps in identifying important medicinal plants and may also lead to the development of new or important pharmaceutical drugs [32] with future bioprospecting potential [33,34].

Many ethnopharmacological studies have been conducted in Nepal [15,35-37]; however, many parts of the country and communities remain unexplored. One of the unexplored communities is the Tamang community of the Makawanpur district, which constitutes $47.3 \%$ of the total district population [19]. In Nepal, the Tamang community is the fifth largest community, with $5.6 \%$ of the total population of the country [19], who mostly live in mountainous or hilly regions [35]. The Makawanpur district is one of the major Tamang dwelling areas in the hilly region of Nepal. Few ethnobotanical studies have been conducted in this district [38-48], although a considerable number of ethnobotanical studies relating to the Tamang community have been conducted in different parts of Nepal [20,22,49-57]. Previous studies in different parts of Nepal have revealed that the Tamang people have a unique culture and a rich traditional knowledge [20,35,55]. However, ethnopharmacological studies specifically targeting the Tamang community of the Makawanpur district are lacking, as are the validation of traditional uses. Therefore, in the present study, we aimed to document indigenous knowledge of the use of medicinal plants in the Tamang community of the Makawanpur district. We hypothesized that the Tamang people in Makawanpur have specialized knowledge of the use of plants, and a wealth of information on a wide range of medicinal plants is expected from the district because the Makawanpur district is located in an area that is rich in biodiversity. We also expected that the Tamang people use different species or known species for different diseases than previously reported because they form part of a distinct ethnic group with a unique identity. Our specific objectives were to address the following questions: (i) Which plant species are used against different diseases by the Tamang people in the Makawanpur district? (ii) What are the modes of preparation and administration of traditional herbal medicines? (iii) Is there any pharmacological or phytochemical evidence for the traditional uses?

\section{Methods}

\section{Study area}

The study areas included the Hadigaun, Aambhanjyang and Tistung village development committees (VDCs) (Figure 1). Study areas were selected based on a large

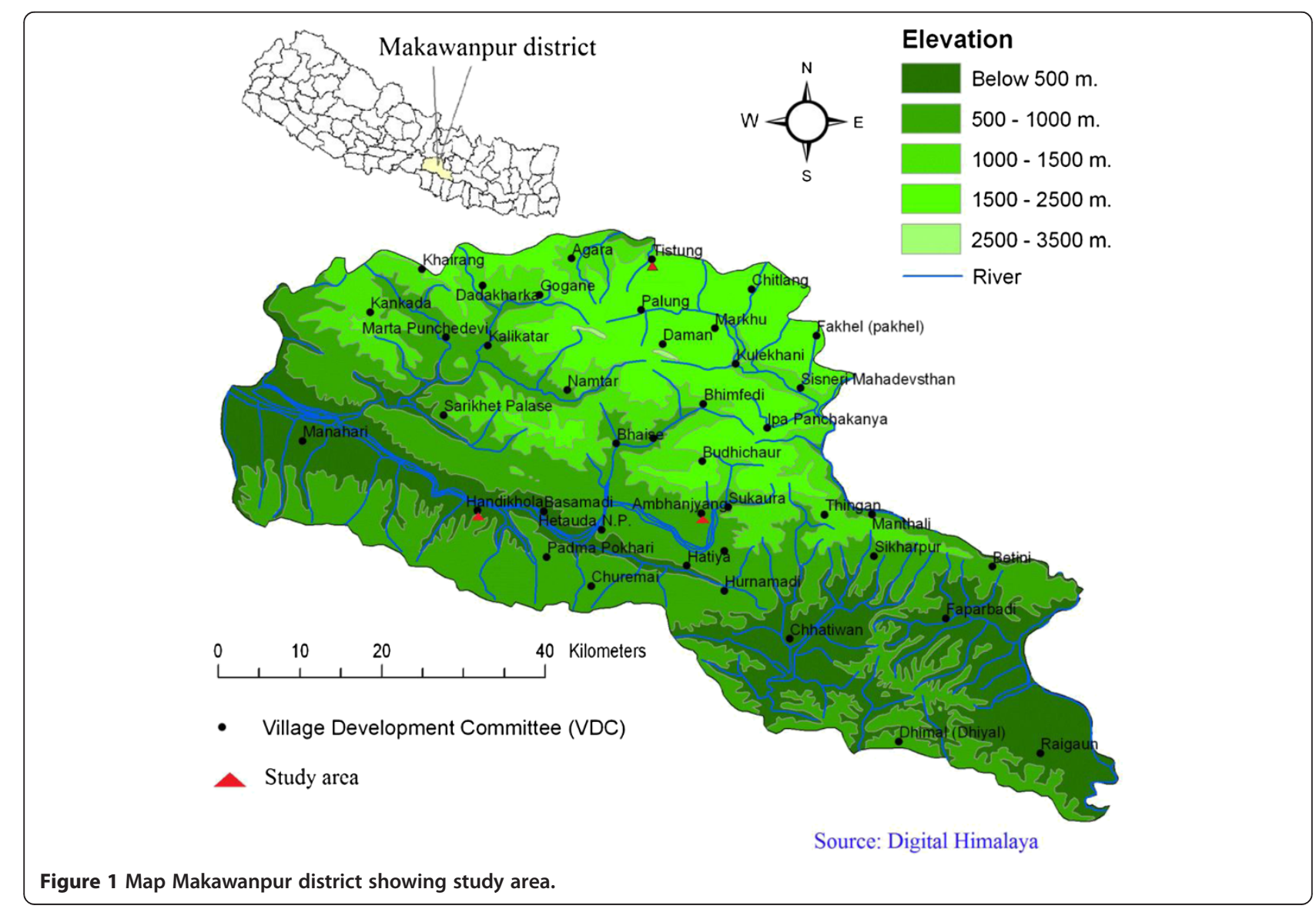


Tamang population residing in the area compared with the population of other communities. Field visits were conducted in March 2011 and May 2011 because it is the peak time for plant growth. The duration of one field visit at a site ranged from 4 to 10 days.

The total number of households in Hadigaun was 3155, with 8900 males and 8970 females. The total number of households in Aambhanjyang was 1519, with 4251 males and 4279 females, and the total number of households in Tistung was 1190, with 3293 males and 3293 females [19]. The types of vegetation differed between sites. In Hadikhola (200-1000 m asl), tropical forest is present, with Shorea robusta as the dominant species and common associates of Terminalia alata, Adina cordifolia, Anogeisus latifolia, Lagerstroemia parviflora, Dillenia pentagyna, Syzygium cumini, and Semicarpus anacardium. There was an Acacia catechu-Dalbergia sissoo community along streams and rivers and a tropical deciduous riverine forest with Bombax ceiba, Holoptelea integrifolia, and Trewia nudiflora together with other species in the Shorea robusta forest. In Aambhanjyang (550-1680 $\mathrm{m}$ asl), there was subtropical forest with the remains of a Shorea robusta forest at lower elevations, and a Schima-Castanopsis forest at higher elevations. Schima wallichii occurs throughout, with Castanopsis indica more common below $1200 \mathrm{~m}$, and Castanopsis tribuloides above this elevation. At higher elevations, there was riverine forest with Toona, and Albizzia species. This forest occurs in narrow strips along streams and is mixed in composition, with Toona ciliata, Albizzia mollis, and Pandanus nepalensis. In Tistung (1500-2500 $\mathrm{m}$ asl), there were pure stands of Pinus roxburgii characterized as lower temperate forest type.

\section{Data collection}

Prior to data collection, the objectives of the study were discussed by organizing a group meeting with local people, teachers, elderly men and women from each VDC. Verbal consent was obtained from the participants, and data were collected in a manner similar to other studies in Nepal [58,59].

The participants were chosen to represent both genders and all age groups. We used semi-structured questionnaires in groups in each study area, and questions aimed to collect information on the types of diseases and presence of plant species and their uses. Thirty people in Hadigaun, 17 in Aambhanjyang and 10 in Tistung area participated in the study, of which 22 were women, primarily housewives aged 25-60 years, and 35 were men 40-79 years old (Additional file 1: Table S1). We also conducted separate in-depth interviews with four local healers using structured questionnaires targeting the specific uses of each plant species. The local healers who participated in in-depth interviews included Saila Syantang (70 years old) in
Tistung, Lal Bahadhur Thing (68 years old) and Bir Bahadhur Parja (70 years old) in Hadikhola, and Chandra Bahadhur Syantang (50 years old) in the Ambhanjyang VDCs. In addition, we also collected information on veterinary use. The information collected through nonstructured questionnaires and structured questionnaires was summarized into a single table providing all plant names, and their uses. The final table included information on vernacular names, life forms, growth, local status, growth ranges, sources, parts used, preparation, administration, and uses. We also included information regarding published studies that cite uses similar to those reported by the Tamang people from the Makawanpur district.

Plant collection and exhibition of plant species were performed during the group or individual interviews. We also asked local people to show plant species obtained outside the Makawanpur district. Most of the collected plants were identified in the field using flora books [60-62]. The identified species were photographed for further references, and unidentified species were preserved as herbarium specimens. The unidentified plant specimens were stored between paper sheets in an herbarium press, and tightened to prevent distortion of the plant. The paper sheets were changed every day for at least three days. The tightly packed herbarium press was kept in sunlight during the daytime to allow evaporation of the moisture to dry the plant specimen, and to prevent infection with fungi using this natural drying technique [63]. The plants were later identified using the same flora books described above and also by comparison with herbarium specimens deposited at the National Herbarium and Plant Laboratories (KATH), Godawari, Lalitpur, Nepal. All specimens collected were deposited at KATH. We followed the nomenclature of Press et al. (2000) [64].

\section{Comparing traditional knowledge}

The uses of plant species described by the Tamang people in the Makawanpur district were compared with several studies related to the Makawanpur district [38-43,45-48] and Tamang communities from different parts of Nepal $[20,22,49-57,65]$. We also consulted several books that described medicinal plants throughout Nepal. These books were the outcome of studies conducted in different parts of Nepal [35,66] or specific regions [67] or review books on medicinal plants $[15,36,68]$. We also consulted recent studies that were not included in the books described above $[7,17,20,29,30,47,59,69-72]$. The pharmacological studies included tests of crude or purified plant extracts against a particular type of microbe or disease. Phytochemical studies included isolation of compound (s), and such compounds were sometimes tested against microbes or diseases. To identify the studies, we searched for relevant literature on plant species in different electronic databases (ISI Web of Science, MEDLINE, Science 
Direct, Scopus, and Google Scholar) and by searching masters and $\mathrm{Ph}$. D. dissertations at Tribhuvan University Central Library, Kirtipur, Nepal.

\section{Results}

\section{Medicinal plant diversity, and uses}

The present survey found 161 plant species belonging to 86 families and 144 genera that are used to cure 89 human ailments by the Tamang people in the Makawanpur district (Additional file 2: Table S2). Angiosperms constituted the highest number of plants species (132 dicotyledones, and 18 monocotyledones) followed by pteridophytes (6), gymnosperms (3), and mushrooms (1). Herbs were the major sources of medicine (45\%), followed by trees (33\%), and shrubs (23\%).

The highest number of plant species was used for gastrointestinal-related diseases followed by cuts and wounds, and fever. Thirty-five plant species were used for other categories (antidotes, improved lactation, cooling agents, tonics, and for religious purposes) (Figure 2).

Some of the plants were edible and were also used as food (Dryoathyrium boryanum, Musa paradisiaca, Myrica esculenta, Psidium guajava, and Rubus ellipticus). Wide varieties of trees or shrubs were major sources of fuel or sometimes timber for daily uses (e.g., construction, and making wooden tools such as ploughs). Other species were used for religious purposes (e.g., Shorea robusta, Pinus roxburghii, and Pinus wallichiana).

\section{Parts, preparation, modes of use, and harvesting}

The plant parts used for various types of ailments included the underground parts (roots, rhizomes, bulbs, and tubers), young shoots, stems, bark and wood, leaves and petioles, flowers, fruits and seeds, resins, and the whole plant. The most frequently used plant parts were fruits and seeds (for 51 different plant species), followed by leaves and petioles (37 plant species). The whole plant was also frequently used (38 plant species) (Figure 3).

The plants were used in various forms for different ailments. The most frequently used form was powder, followed by paste, and juice. Many species were also used as medicine in a raw form (Figure 4). The primary mode of administration of medicine to cure different ailments was oral (56.47\%), followed by external or topical application (40.59\%). Three species were used as a toothbrush (Hedera nepalensis, Prunus cornuta, and Smilax zeylanica). Vitex negundo was used by fuming and administered through the nasal passage. Drymaria diandra was mixed with water for steam therapy.

Plant species were primarily harvested from the wild (147 plant species), and only a few species were cultivated (14 plant species) (Additional file 2: Table S2). Plants were generally collected as per local needs without any rules, and regulations. Four species (Malus sylvestris, Nardostachys grandiflora, Pycnoporus cinnabarinus, and Valeriana jatamansii) were obtained from the Rasuwa district, and one species from its only habitat in western Nepal (Pterocarpus marsupium) (Additional file 2: Table S2).

\section{Differences between respondents}

During the interviews, we found that elderly people were most familiar with the various types of medicinal plant species. The majority of the participants knew plants used for common ailments such as stomach problems, cough, and cold. When comparing males and females, females were better at identifying plant species than males because they regularly visit forests for firewood or fodder collection. The majority of young people were not familiar with plant species, and their uses. The local healers participated and described the uses of the plants

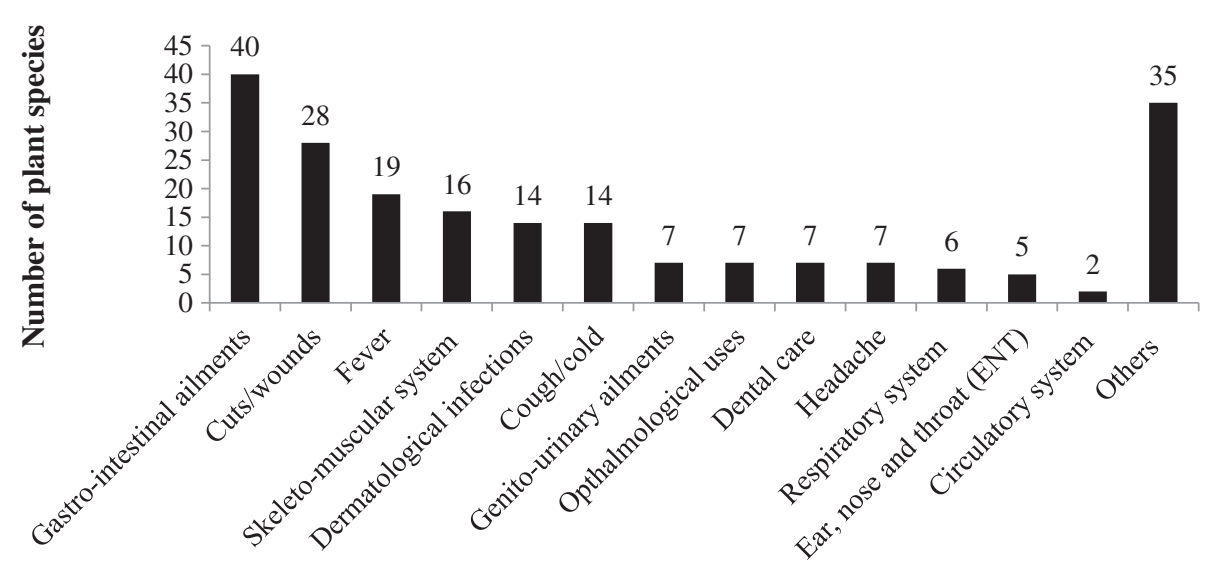

Categories of ailments

Figure 2 Use frequency of plant species in different disease categories by Tamang community in Makawanpur district. The plant species might have repeated for each disease category. 


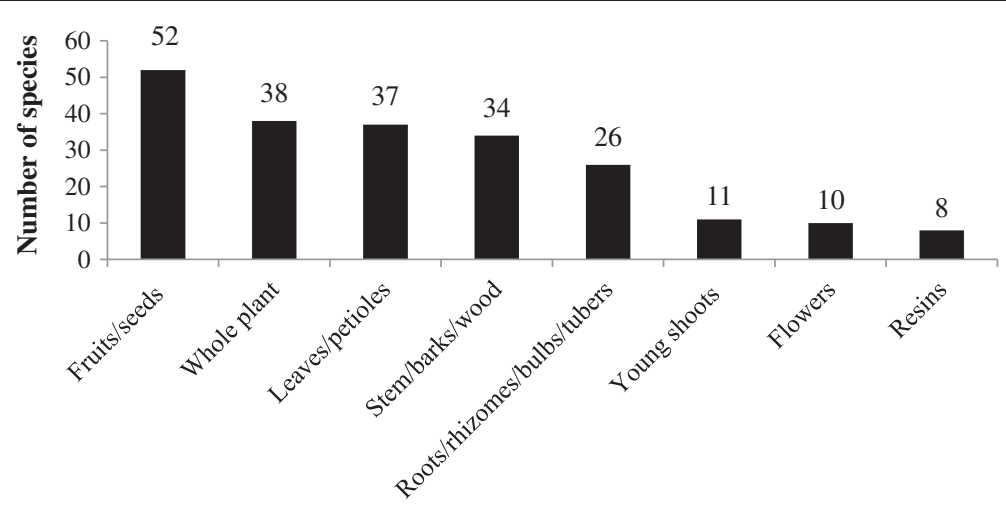

Plant parts

Figure 3 Use frequency of different plant parts by Tamang community in Makawanpur district.

but were reluctant to share their full indigenous knowledge on the uses of plants, and did not reveal the detailed doses of administration. Most of the people reported that traditional knowledge was passed through verbal communication, and repeated practice. The healers reported that knowledge of the use of plants was passed to one of their family members without revealing this knowledge to the others.

\section{Veterinary medicines}

There were 14 plant species belonging to 14 families used for veterinary diseases. Most of these plants were given as the whole plant by oral administration, and a few were used topically. The plants were used for a wide variety of diseases, such as diarrhea, wounds, infections, and foot-and-mouth disease (Table 1).

\section{Comparison of reported uses}

From a literature comparison, we found that there were similar use reports for 93 plant species used against 64 different ailments in various studies. Although 68 plant species were described as medicinal in various studies, 55 different uses by the Tamang people were not found in any of the literature compared. Moreover, five plant species (Gaultheria hookeri, Malvaviscus arboreus, Osmanthus suavis, Sambucus hookeri, and Schoenoplectus juncoides) were not found as medicinal plant species in any of the studies we considered for comparison (Additional file 2: Table S2).

Pharmacological and phytochemical studies were found for 60 plant species (Additional file 3: Table S3). A comparison of Tamang use with pharmacological and phytochemical studies showed complete or partial consistency

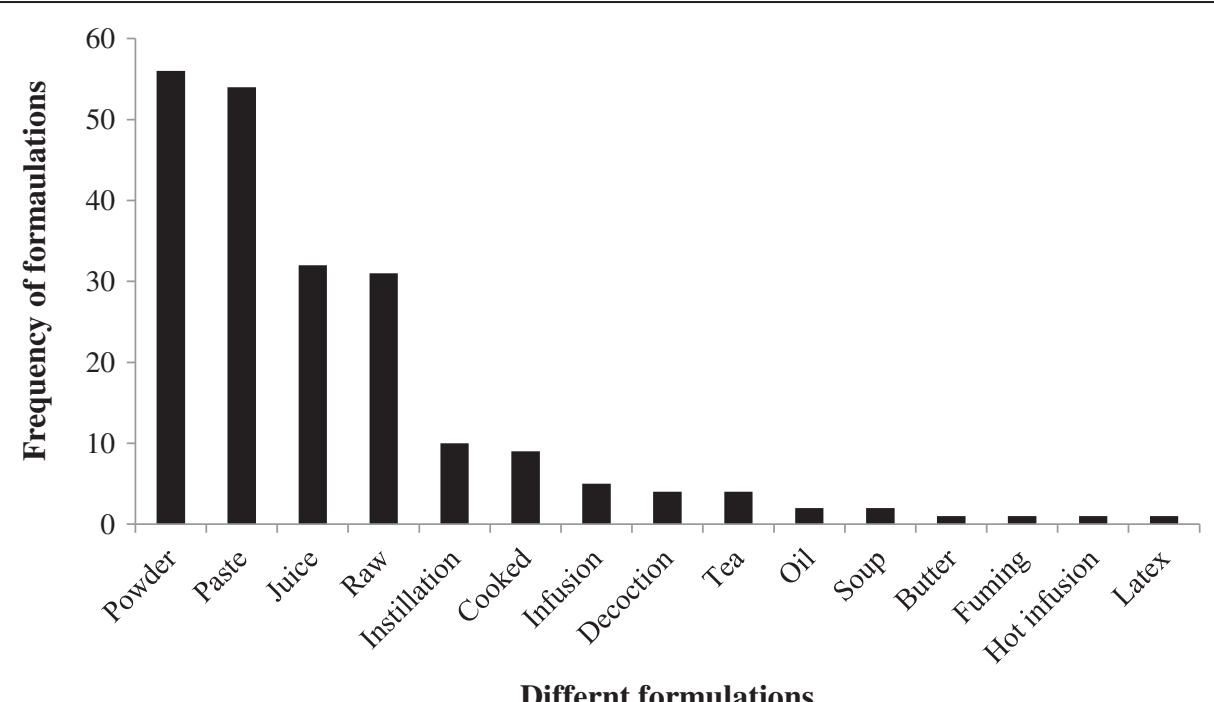

Figure 4 Use frequency of different formulations used adopted by Tamang community in Makawanpur district. 
Table 1 Veterinary uses of medicinal plants in Makawanpur area

\begin{tabular}{lll}
\hline Scientific Names & Administration & Uses \\
\hline Asparagus racemosus Willd. & Oral & Better milk production \\
Auricularia polytricha (Mont.) Sacc. & Oral & Dyspepsia \\
Bauhinia malabarica Roxb. & Topical & Wounds in neck \\
Cannabis sativa L. & Oral & Diarrhea \\
Cissampelos pareira L. & Oral & To kill tapeworm \\
Coriandrum sativum L. & Oral & Better milk production \\
Didymocarpus albicalyx C. B. Clarke & Oral & Energies the weak animals \\
Elephantopus scaber L. & Oral/Topical & Sex stimulants in female animals \\
Lindera neesiana (Wall. ex Nees) Kurz & Oral & Diarrhea \\
Mangifera indica L. & Topical & Eye problems \\
Persicaria chinensis (L.) H. Gross & Oral & Diuretic \\
Viscum album L. & Oral/Topical & Wide ranges of diseases especially for buffalos \\
Zanthoxylum oxyphyllum Edgew. & Topical & To kill lice and teaks \\
Zingiber officinale Rosc. & Oral/Topical & Foot mouth diseases and other communicable diseases \\
\hline
\end{tabular}

for 52 of 60 plant species. The studies for eight plant species (Astilbe rivularis, Citrus aurantifolia, Cucumis sativus, Eupatorium adenophorum, Pinus wallichiana, Rhododendron arboreum, Scutellaria repens and Valeriana jatamansii) were related to the isolation of different compounds, but the compounds had not been pharmacologically tested against the disease mentioned by Tamangs of Makawanpur (Additional file 3: Table S3).

\section{Discussion}

\section{Traditional uses of medicinal plants by the Tamang people in Makawanpur}

In the present study, we reported 161 plant species that are used by the Tamang people in the Makawanpur district as medicine. The number of reported medicinal plant species is higher than in studies carried out in the Chepang community [45], in various communities [40], in the Daman area in the Makawanpur district [46], and in the Tamang community in the Rasuwa district [20] in Nepal. This observation shows that the Tamang people in the Makawanpur district have extensive knowledge of how to use plants as medicine against different diseases. The dominance of herbs followed by trees, and shrubs is consistent with the different studies from Nepal $[7,17,18,20]$. The preference for herbs over other forms may be because herbs are more abundant [7], and more easily collected and transported [20].

The most frequently cured disease category was gastrointestinal diseases. Similar to other rural communities, the prevalence of gastrointestinal diseases in the Tamang community is due to poor sanitation, and contaminated drinking water [73]. The plants are used as food, timber and fuel, and also as veterinary medicine in the Makawanpur district, demonstrating that the residents fulfill different requirements from plants as reported in various previous studies [15,35,36].

Fruits and seeds, and leaves and petioles are most frequently used because they are easily available. The preference for fruits and seeds or leaves and petioles for primary health care shows that indigenous knowledge is quite specialized because these parts contain high concentrations of bioactive compounds [74], comparable to underground plant parts $[75,76]$.

\section{Comparison of reported uses}

Although 93 plant species showed similar uses with other studies from different parts of Nepal (Additional file 2: Table S2), we found pharmacological or phytochemical studies for only 60 of these plant species (Additional file 3 : Table S3). These 52 medicinal plant species have good bioprospecting potential because they are scientifically proven to be important in cures for different diseases, which demonstrates that the Tamang people in the Makawanpur area have reliable knowledge on the use of plants for their primary health care.

When looking across the different studies, we found that uses for five different plant species were not exactly the same as previously reported, but the previously reported uses were similar. For example, we reported that Aconitum ferox was used for toothache, and was described as an analgesic in other studies [15,68]. Amaranthus spinosus, which is used against skin diseases in Makawanpur, is reported as being used for wounds [38], to remove pus in boils and for various skin problems such as boils, burns, pimples, and eczema [35]. Likewise, Artemisia indica, which is reported to be used for scabies, was previously reported as being used for bathing children [47], lacerations [20] or against wounds or ringworm [35]. Cassia fistula, used for digestion 
problems in the studied area, was previously reported as a laxative or appetite stimulant in Nepal $[35,43]$. Cinnamomum tamala, reported to be beneficial for digestion, was previously described as a carminative [15] or used for diarrhea [35].

Given that we have revealed previously unreported uses for 68 of 161 species, it is important to have explicit documentation of the use of plants in different parts of Nepal so that the valuable but disappearing traditional knowledge will be preserved. Further investigation of plant species related to pharmacological and phytochemical studies may lead to the discovery of new bioactive compounds for treating life-threatening illnesses [77,78].

\section{Harvesting and sustainable management of medicinal plants}

Harvesting of plant species from the wild is a common trend worldwide [79-81]. Seven of the species used by the Tamang people in Makawanpur are protected [82], including Acacia catechu, Bombax ceiba, Juglans regia, Shorea robusta, and Taxus wallichiana. None of these plant species was traded outside the study area. However, many of these plant species (e.g., Acacia catechu, Acorus calamus, Asparagus racemosus and Paris polyphylla) possess the potential to boost the economy in the future [83]. The use of plants from the wild in these regions demonstrates that medicinal plants face the long-term danger of depletion, and therefore, their cultivation should be initiated to save this component of biodiversity, and maintain the existing ecosystems. In addition, populations of many medicinal plant species are often reduced by deforestation, habitat encroachment, shifting cultivation, forest fires, grazing, and other anthropogenic activities. Therefore, cultivation techniques for several medicinal plant species are currently being tested at Daman Botanical Garden and Tistung Botanical Garden (e.g., Acorus calamus, Amomum subulatum, Asparagus racemosus, Astible rivularis, Berginia ciliata, Lobelia pyrimidalis, and Mentha piperata) by the Department of Plant Resources under the Ministry of Forest and Soil Conservation, Nepal. Knowledge of the cultivation techniques required should be transferred to the local farmers in the study area.

\section{Conclusions}

The Tamang community in the Makawanpur district has rich indigenous knowledge of the use of medicinal plants to maintain their primary health. Traditional herbal remedies are important and effective in the Tamang community because many traditional uses are scientifically proven through phytochemical and pharmacological studies. However, a large number of plant species remain untested for bio-efficacy and toxicity. Such tests may reveal novel remedies that have bioprospecting potential. Most of the plant species are harvested in the wild; the practice of cultivation and domestication of at least the most rare and most highly used plant species is needed for sustainability.

\section{Additional files}

Additional file 1: Table S1. Details of informants interviewed in Hadigaun, Aambhanjyang and Tistung village development committees of Makawanpur district.

Additional file 2: Table S2. Medicinal plants used by Tamang community in Makawanpur district, central Nepal [38,84-93].

Additional file 3: Table S3. Comparison of local use and phytochemical and pharmacological studies of medicinal plants [94-186].

\section{Competing interests}

The authors declare that they have no competing interests.

\section{Authors' contributions}

$\mathrm{DL}$ carried out field research. MR supervised the work. DL, MR, BT and ZM analysed the data and wrote the manuscript. All authors approved the final version of the manuscript.

\section{Acknowledgements}

We are thankful to the local people who shared their knowledge on uses of plants. The study was supported by GAČR 13-10850P and partly by institutional support RVO 67985939. This work was also partly supported by the grant No. CZ.1.05/1.1.00/02.0073 of the MSMT.

\section{Author details}

${ }^{1}$ Department of Plant Resources Office, Ministry of Forest and Soil Conservation, Thapathali, Kathmandu, Nepal. ${ }^{2}$ Institute of Botany, Academy of Sciences of the Czech Republic, Zamek 1, Průhonice 25243, Czech Republic. ${ }^{3}$ Department of Biodiversity Research, Global Change Research Centre AS ČR, Na sádkách 7, České Budějovice 37005, Czech Republic. ${ }^{4}$ Institute for Environmental Studies/Department of Botany, Faculty of Science, Charles University, Benatska 2, Prague 12801, Czech Republic.

Received: 8 March 2013 Accepted: 30 November 2013 Published: 10 January 2014

\section{References}

1. Sumner J: The Natural History of Medicinal Plants. 1st edition. Portland, Oregon, USA: Timber Press; 2000.

2. Traditional Medicine: Fact Sheet 34. [http://www.who.int/inf-fs/en/fact134. html] (accessed on 28 2013).

3. Bernal J, Mendiola JA, Ibáñez E, Cifuentes A: Advanced analysis of nutraceuticals. J Pharm Biomed Anal 2011, 55:758-774.

4. Jordan SA, Cunningham DG, Marles RJ: Assessment of herbal medicinal products: Challenges, and opportunities to increase the knowledge base for safety assessment. Toxicol Appl Pharmacol 2010, 243:198-216.

5. Abdullahi AA: Trends and challenges of traditional medicine in Africa. Afr J Tradit Complement Altern Med 2011, 8(5 Suppl):115-123.

6. Quinlan MB, Quinlan RJ: Modernization and medicinal plant knowledge in a Caribbean horticultural village. Med Anthropol Q 2007, 21:169-192.

7. Rokaya MB, Münzbergová Z, Timsina B: Ethnobotanical study of medicinal plants from the Humla district of western Nepal. J Ethnopharmacol 2010, 130:485-504.

8. Shanley P, Luz L: The impacts of forest degradation on medicinal plant use and implications for health care in eastern Amazonia. BioScience 2003, 53:573-584.

9. Telwala Y, Brook BW, Manish K, Pandit MK: Climate-induced elevational range shifts and increase in plant Species richness in a Himalayan biodiversity epicentre. PLOS ONE 2013, 8:e57103.

10. Teshome-Bahiru W: Impacts of urbanisation on the traditional medicine of Ethiopia. Anthropologist 2005, 8:43-52.

11. Cox PA, Balick MJ: The ethnobotanical approach to drug discovery. Sci Am 1994, 270:82-87.

12. Etkin NL: Anthropological methods in ethnopharmacology. J Ethnopharmacol 1993, 38:93-104. 
13. Berkes F, Colding J, Folke C: Rediscovery of traditional ecological knowledge as adaptive management. Ecol App/ 2000, 10:1251-1262.

14. Watson A, Alessa L, Glaspell B: The relationship between traditional ecological knowledge, evolving cultures, and wilderness protection in the circumpolar north. Conserv Ecol 2003, 8:2

15. Baral SR, Kurmi PP: A Compendium of Medicinal Plants in Nepal. Kathmandu, Nepal: Rachana Sharma; 2006.

16. Rijal A: Living knowledge of the healing plants: Ethno-phytotherapy in the Chepang communities from the Mid-Hills of Nepal. J Ethnobiol Ethnomedicine 2008, 4:23.

17. Shrestha PM, Dhillion SS: Medicinal plant diversity and use in the highlands of Dolakha district, Nepal. J Ethnopharmacol 2003, 86:81-96.

18. Rokaya MB, Münzbergová Z, Shrestha MR, Timsina B: Distribution patterns of medicinal plants along an elevational gradient in central Himalaya, Nepal. J Mt Sci 2012, 9:201-213.

19. CBS: National Population and Housing Census 2011 (National Report). Kathmandu, Nepal: Central Bureau of Statistics, Government of Nepal; 2012

20. Uprety Y, Asselin H, Boon EK, Yadav S, Shrestha KK: Indigenous use and bio-efficacy of medicinal plants in the Rasuwa District, Central Nepal. J Ethnobiol Ethnomedicine 2010, 6:3

21. Krenn L, Presser A, Pradhan R, Bahr B, Paper DH, Mayer KK, Kopp B: Sulfemodin 8-O-beta-D-glucoside, a new sulfated anthraquinone glycoside, and antioxidant phenolic compounds from Rheum emodi. J Nat Prod 2003, 66:1107-1109.

22. Taylor RSL, Edel F, Manandhar NP, Towers GHN: Antimicrobial activities of southern Nepalese medicinal plants. J Ethnopharmacol 1996, 50:97-102.

23. Taylor RSL, Manandhar NP, Towers GHN: Screening of selected medicinal plants of Nepal for antimicrobial activities. J Ethnopharmacol 1995, 46:153-159.

24. Adzu B, Tarfa F, Amos S, Gamaniel KS: The efficacy of Sphaeranthus senegalensis Vaill extract against diarrhoea in rats. J Ethnopharmacol 2004, 95:173-176.

25. Alam MMA, Javed K, Jafri MA: Effect of Rheum emodi (Revand Hindi) on renal functions in rats. J Ethnopharmacol 2005, 96:121-125

26. Arunachalam K, Parimelazhagan T: Antidiabetic activity of Ficus amplissima Smith. bark extract in streptozotocin induced diabetic rats. J Ethnopharmacol 2013, 147:302-310.

27. Rokaya MB, Maršík P, Münzbergová Z: Active constituents in Rheum acuminatum and Rheum australe (Polygonaceae) roots: A variation between cultivated and naturally growing plants. Biochem Syst Ecol 2012, 41:83-90.

28. Gaire BP, Subedi L: Medicinal plant diversity and their pharmacological aspects of Nepal Himalayas. Pharmacogn J 2011, 2:6-17.

29. Kunwar RM, Burlakoti C, Chowdhary C, Bussman R: Medicinal plants in western Nepal: Indigenous uses and pharmacological validity. Med Aromat Plant Sci Biotechnol 2010, 4:28-42.

30. Kunwar RM, Shrestha KP, Bussmann RW: Traditional herbal medicine in Far-west Nepal: a pharmacological appraisal. J Ethnobiol Ethnomedicine 2010, 6:35

31. Maroyi A: Traditional use of medicinal plants in south-central Zimbabwe: review and perspectives. J Ethnobiol Ethnomedicine 2013, 9:31.

32. Newman DJ, Cragg GM: Natural products as sources of new drugs over the last 25 Years. J Nat Prod 2007, 70:461-477.

33. Douwes $E$, Crouch NR, Edwards TJ, Mulholland DA: Regression analyses of southern African ethnomedicinal plants: informing the targeted selection of bioprospecting and pharmacological screening subjects. J Ethnopharmacol 2008, 119:356-364

34. Soejarto DD, Fong HHS, Tan GT, Zhang HJ, Ma CY, Franzblau SG, Gyllenhaal C, Riley MC, Kadushin MR, Pezzuto JM, Xuan LT, Hiep NT, Hung NV, Vu BM Loc PK, Dac LX, Binh LT, Chien NQ, Hai NV, Bich TQ, Cuong NM, Southavong B, Sydara K, Bouamanivong S, Ly HM, Thuy TV, Rose WC, Dietzman GR: Ethnobotany/ethnopharmacology and mass bioprospecting: Issues on intellectual property and benefit-sharing. J Ethnopharmacol 2005, 100:15-22.

35. Manandhar NP: Plants and People of Nepal. Portland, Oregon, USA Timber Press; 2002.

36. Rajbhandari KR: Ethnobotany of Nepal. Kathmandu, Nepal: WWF Nepal Program; 2001

37. Shrestha KK, Tiwari NN, Rajbhandari S, Poudel RC, Uprety Y: Ethnobotany in Nepal: Review and Perspectives. Kathmandu, Nepal: WWF Nepal Program; 2004.
38. Basnet B, Joshi R, Lekhak HD: Ethnobotanical survey of Chepang tribe of Makawanpur district, Nepal. In Environ Agric Biodivers Agric Pollut South Asia. Edited by Jha PK, Baral SR, Karmacharya SB, Lekhak HD, Lacoul P, Baniya CB. Kathmandu, Nepal: Ecological Society (ECOS); 2001:245-252.

39. Bhattarai NK: Folk anthelmintic drugs of central Nepal. Pharm Biol 1992, 30:145-150.

40. Bhattarai NK: Folk herbal medicines of Makawanpur district, Nepal. Pharm Biol 1991, 29:284-295.

41. Hasan MK, Gatto P, Jha PK: Traditional uses of wild medicinal plants and their management practices in Nepal-A study in Makawanpur district. Int J Med Aromat Plants 2013, 3:102-112.

42. Khan MH: Documentation of indigenous knowledge in the Chepang community of Shakti Khor VDC, Chitawan. In Ethnobot Conserv Community Dev. Edited by Shrestha KK, Jha PK, Shengji P, Rastogi A, Rajbhandary S, Joshi M. Kathmandu, Nepal: Ethnobotanical Society of Nepal; 1998:96-101.

43. Manandhar NP: An inventory of some vegetable drug resources of Makawanpur District, Nepal. Fitoterapia 1995, 66:231-238.

44. Manandhar NP: Folklore medicine of Chitwan district, Nepal. Ethnobotany 1990, 2:31-38

45. Manandhar NP: Medicinal plants used by Chepang tribes of Makawanpur District, Nepal. Fitoterapia 1989, 60:61-68.

46. Pathak L, Pandey SR: Ethno-medicinal plants of Daman area, Central Nepal. Plant Resour Bull 2005, 26:30-32.

47. Uprety Y, Boon E, Poudel RC: Traditional Use of Plant Resources by Bankariya Ethnic Group in Makawanpur District, Central Nepal. Germany: GRIN Verlag; 2008.

48. Uprety Y, Poudel RC, Shrestha KK, Rajbhandary S, Tiwari NN, Shrestha UB Asselin H: Diversity of use and local knowledge of wild edible plant resources in Nepal. J Ethnobiol Ethnomedicine 2012, 8:16.

49. Kharel S: Ethnomycological study on wild edible mushrooms of Bhardeo VDC, Lalitpur, Nepal, M.Sc. Thesis. Kirtipur, Nepal: Central Department of Botany, Tribhuvan University; 1998

50. Manandhar NP: Medicinal plant-lore of Tamang tribe of Kabhrepalanchok district, Nepal. Econ Bot 1991, 45:58-71.

51. Shrestha I, Shrestha K: Ethno-medico-botanical studies of Langtang National Park, Nepal. In Proceeding Nepal-Jpn Jt Symp Conserv Util Himal Med Resour. Kathmandu, Nepal: Ministry of Forest and Soil Conservation- HMG/N, Department of Plant Resources and Society for the Conservation and Development of Himalayan Medicinal Resources (SCDHMR), Japan; 2000:178-181.

52. Shrestha I, Inglis A, Shrestha K: Documenting and mapping medicinal plants of Lantang National Park, central Nepal. In Proceeding Int Semin Mt. Kathmandu, Nepal: Royal Nepal Academy of Science and Technology (RONAST); 2003:361-371.

53. Shrestha P: Ethnobotanical observation on the Tamangs of Kathmandu valley. In Proc Natl Conf Sci Technol April 24-29 1988 RONAST Katmandu. Royal Nepal Academy of Science and Technology (RONAST); 1989:353-358.

54. Shrestha P: Contribution to the ethnobotany of the Tamangs of Kathmandu valley. Cent Nepal Asian Stud 1988, 15:247-266.

55. Tamang G: An Ethnobiological study of the Tamang people. Our Nat 2003, 1:37-41.

56. Tamang G: Ethnobiology of Tamang Tribe (A case study of Gorsyang VDC), M Sc. Thesis. Kathmandu, Nepal: Central Department of Zoology, Tribhuvan University; 1998

57. Toffin G, Wiart J: Recherches surl'ethnobotanidue des Tamang dumassif du Ganesh Himal Nepal Central): Les plantes non cultivees. J Agric Trad Bota Appl 1985, 32:127-175.

58. Kunwar RM, Mahat L, Acharya RP, Bussmann RW: Medicinal plants, traditional medicine, markets and management in far-west Nepal. J Ethnobiol Ethnomedicine 2013, 9:24.

59. Uprety $Y$, Poudel RC, Asselin H, Boon E: Plant biodiversity and ethnobotany inside the projected impact area of the Upper Seti Hydropower Project, Western Nepal. Environ Dev Sustain 2011, 13:463-492.

60. Polunin O, Stainton A: Flowers of the Himalaya. New Delhi, India: Oxford University Press; 1984.

61. Stainton A: Flowers of the Himalaya: A Supplement. New Delhi, India: Oxford University Press; 1988.

62. Storrs A, Storrs J: Trees and Shrubs of Nepal and the Himalayas. New Dehli, India: Books Faith India; 1998

63. Bridson DM, Forman L: The Herbarium Handbook. Kew: Royal Botanic Gardens; 1998. 
64. Press JR, Shrestha KK, Sutton DA: Annotated Checklist of the Flowering Plants of Nepal. Kathmandu: Natural History Museum, London and Central Department of Botany, Tribhuvan University; 2000.

65. Mikage M: Field research on the medicinal plant researches around the Tamang Village, Kaski district, west Nepal. News/ Himal Bot 2000 27:1-5.

66. Ghimire SK, Sapkota IB, Oli BR, Parajuli-Rai R: Non-Timber Forest Products of Nepal Himalaya: Database of Some Important Species Found in the Mountain Protected Areas and Surrounding Regions. 1st edition. Kathmandu, Nepal: WWF; 2008.

67. Lama YC, Ghimire SK, Aumeeruddy-Thomas Y: Medicinal Plants of Dolpo: Amchis' Knowledge and Conservation. Kathmandu, Nepal: Worldwide Fund for Nature Conservation (WWF) Nepal; 2001.

68. Joshi KK, Joshi SD: Genetic Heritage of Medicinal and Aromatic Plants of Nepal Himalayas. Kathmandu, Nepal: Buddha Academic Publications; 2001.

69. Bhattarai K, Maren I, Chaudhary R: Medicinal plant knowledge of the Panchase region in the middle hills of the Nepalese Himalayas. Banko Janakari 2011, 21:31-39.

70. Joshi A, Joshi K: Plant diversity and ethnobotanical notes on tree species of Syabru village, Langtang national park, Nepal. Ethnobot Leafl 2009, 13:651-664.

71. Kunwar RM, Uprety Y, Burlakoti C, Chowdhary CL, Bussmann RW: Indigenous use and ethnopharmacology of medicinal plants in far-west Nepal. Ethnobot Res Appl 2009, 7:005-028.

72. Shrestha KK, Ghimire SK: Plant Diversity Inventory of the Proposed Kanchunjunga Conservation Area (Ghunsa and Simbua Valley). Kathmandu, Nepal: WWF Nepal Program; 1996

73. Anonymous: People's Perception on Sanitation: Findings from Nepal. GPO Box: 20214, Kathmandu, Nepal: WaterAid in Nepal; 2011:Vii+64

74. Harris CS, Burt AJ, Saleem A, Le PM, Martineau LC, Haddad PS, Bennett SAL, Arnason JT: A single HPLC-PAD-APCI/MS method for the quantitative comparison of phenolic compounds found in leaf, stem, root and fruit extracts of Vaccinium angustifolium. Phytochem Anal 2007, 18:161-169.

75. Giday M, Asfaw Z, Elmqvist T, Woldu Z: An ethnobotanical study of medicinal plants used by the Zay people in Ethiopia. J Ethnopharmacol 2003, 85:43-52.

76. Srithi K, Balslev H, Wangpakapattanawong P, Srisanga P, Trisonthi C: Medicinal plant knowledge and its erosion among the Mien (Yao) in northern Thailand. J Ethnopharmacol 2009, 123:335-342.

77. Cragg GM, Newman DJ: Plants as a source of anti-cancer and anti-HIV agents. Ann Appl Biol 2003, 143:127-133.

78. Heinrich M, Gibbons S: Ethnopharmacology in drug discovery: an analysis of its role and potential contribution. J Pharm Pharmacol 2001, 53:425-432.

79. Abe $\mathrm{R}$, Ohtani $\mathrm{K}$ : An ethnobotanical study of medicinal plants and traditional therapies on Batan Island, the Philippines. J Ethnopharmacol 2013, 145:554-565.

80. Cakilcioglu U, Khatun S, Turkoglu I, Hayta S: Ethnopharmacological survey of medicinal plants in Maden (Elazig-Turkey). J Ethnopharmacol 2011, 137:469-486.

81. Kadir MF, Bin Sayeed MS, Mia MMK: Ethnopharmacological survey of medicinal plants used by indigenous and tribal people in Rangamati, Bangladesh. J Ethnopharmacol 2012, 144:627-637.

82. HMGN: Forest Act, 1993 and Forest Regulation, 1995. Kathmandu, Nepal: Ministry of Forests and Soil Conservation; 1993.

83. Tiwari NN, Poudel RC, Uprety Y: Study on Domestic Market of Medicinal and Aromatic Plants (MAPS) in Kathmandu Valley. Kathmandu, Nepal: Winrock International; 2004:46.

84. Anonymous: Medicinal Plants of Nepal. Kathmandu, Nepal: Ministry of Forest and Soil Conservation, Department of Plant Resources; 1997 [3]

85. Joshi SG: Medicinal Plants. Delhi, India: Oxford \& IBH Publishing Company Pvt. Limited; 2000

86. Anonymous: Medicinal Plants of Nepal. Kathmandu, Nepal: Ministry of Forest and Soil Conservation, Department of Plant Resources; 2001 [10].

87. Siwakoti M, Siwakoti S: Ethnobotanical uses of plants among the Satar tribes of Nepal. In Ethnobot Midicinal Plants Indian Subcont Eds Maheshwori JK. Jodhapur, India: Scientific publishers; 2000:79-108.

88. Department of Plant Resources (DPR): Fungi of Nepal Part II: Mastigomycotina, Zygomycotina and Ascomycotina. Kathmandu, Nepal: Bulletin of the Department of Plant Resources (DPR), Government of Nepal; 1997 [16].
89. Acharya SK: Folk uses of some medicinal plants of Pawan Nagar, Dang District. J Nat Hist Mus 1996, 15:25-36.

90. Parajuli SP: Ethnobotanical study of at Khandbari municipality of Sankhuwasabha district, Nepal. Banko Jankari 2000, 10:29-34.

91. Bhattacharjee SK: Handbook of Medicinal PlantsFolk Uses of Some Medicinal Plants of Pawan Nagar, Dang District. 3rd edition. Jaipur, India: Pointer publishers; 2001

92. Joshi AR, Edington JM: The use of medicinal plants by two village communities in the central development region of Nepal. Econ Bot 1990, 44:71-83.

93. Pohle P: Useful Plants of Manang District: A Contribution to the Ethnobotany of the Nepal-Himalaya. Stuttgart: Franz Steiner Verlag Wiesbaden GMBH; 1990.

94. Ray D, Sharatchandra K, Thokchom I: Antipyretic, antidiarrhoeal, hypoglycaemic and hepatoprotective activities of ethyl acetate extract of Acacia catechu Willd. in albino rats. Indian J Pharmacol 2006 38:408-413

95. Wang $Y-H$, Wang W-Y, Chang C-C, Liou K-T, Sung Y-J, Liao J-F, Chen C-F, Chang S, Hou Y-C, Chou Y-C, Shen Y-C: Taxifolin ameliorates cerebral ischemia-reperfusion injury in rats through its anti-oxidative effect and modulation of NF-kappa B activation. J Biomed Sci 2006, 13:127-141.

96. Gulzar A, Manjul PS, Anita S, Upendra K, Yatendra K: Preliminary phytochemical and antimicrobial screening of leaves extract of Acacia catechu Willd. J Pharm Res 2010, 3:2583-2584.

97. Parajuli B: Ethnobotany and antimicrobial activities of medicinal plants used diarrhoea and dysentery in Nawalparasi district, Nepal, M.Sc. Thesis. Kirtipur, Nepal: Central Department of Botany, Tribhuvan University; 2004.

98. Baidya MR: Screening and evaluation of in-vitro antimicrobial activity of medicinal plants of Nepal, M.Sc. Thesis. Kirtipur, Nepal: Central Department of Microbilogy, Tribhuvan University; 2001.

99. Dongmo AB, Nguelefack T, Lacaille-Dubois MA: Antinociceptive and anti-inflammatory activities of Acacia pennata wild (Mimosaceae). J Ethnopharmacol 2005, 98:201-206.

100. Chevallier A: The Encyclopedia of Medicinal Plants. London, UK: Dorling Kindersley Ltd.; 1996.

101. Bhogi Hanuman J, Katz A: Diterpenoid alkaloids from ayurvedic processed and unprocessed Aconitum ferox. Phytochemistry 1994, 36:1527-1535.

102. Sabitha RA, Satyakala M, Sandya DV, Suryanarayana MU: Evaluation of antibacterial activity from rhizome extract of Acorus calamus Linn. J Sci Ind Res 2003, 62:529-650.

103. Phongpaichit S, Pujenjob N, Rukachaisirikul V, Ongsakul M: Antimicrobial activities of the crude methanol extract of Acorus calamus Linn. Songklanakarin J Sci Technol 2005, 27:517-523.

104. Valsaraj R, Pushpangadan P, Smitt UW, Adsersen A, Nyman U: Antimicrobial screening of selected medicinal plants from India. J Ethnopharmacol 1997, 58:75-83.

105. Gautam S: Medicinal Plants used to treat respiratory complaints in Nawalparasi District (Southern Nepal) and their antibacterial activities, M.Sc Thesis. Kirtipur, Nepal: Central Department of Botany, Tribhuvan University; 2002.

106. Bhattarai S: Antibacterial Activity of Selected Ethnomedicinal Plants of Nawalparasi District, Central Nepal. Research. Bhaktapur, Nepal: University Grant Commission; 2007.

107. Panthi MP: Plant diversity and resources utilization in Agrhakhanchi and Manang districts of Nepal, Ph.D. Thesis. Kirtipur, Nepal: Central Department of Botany, Tribhuvan University; 2006.

108. Maharjan N, Singh A, Manandhar MD, Basnyat S, Lekhak B, Kalauni SK: Evaluation of antibacterial activities of medicinal plants. Nepal J Sci Technol 2012, 13:209-214.

109. Gyawali R, Bhandari J, Amatya S, Piya E, Pradhan UL, Paudyal R, Shrestha R, Shrestha TM: Antibacterial and cytotoxic activities of high altitude essential oils from Nepalese Himalaya. J Med Plants Res 2013, 7:738-743.

110. Rani $\mathrm{P}$, Khullar N: Antimicrobial evaluation of some medicinal plants for their anti-enteric potential against multi-drug resistant Salmonella typhi. Phytother Res 2004, 18:670-673.

111. Raja SB, Murali MR, Malathi GK, Anbarasu K, Devaraj SN: Effect of aqueous extract of Aegle marmelos fruit on adherence and and $\beta$-Lactam eesistance of enteropathogenic Escherichia coli by down regulating outer membrane protein C. Am J Infect Dis 2009, 5:154-162.

112. Brijesh S, Daswani P, Tetali P, Antia N, Birdi T: Studies on the antidiarrhoeal activity of Aegle marmelos unripe fruit: Validating its traditional usage. BMC Complement Altern Med 2009, 9:47. 
113. Sharrif MM, Verma SK: Aloe vera their chemicals composition and applications: A review. Int J Biol Med Res 2011, 2:446-471.

114. Basmatker G, Jais N, Daud AN: Aloe vera: a valuable multifunctional cosmetic ingredient. Int J Med Aromat Plants 2011, 1:338-341.

115. Chaudhary DN, Singh JN, Singh BP: Effect of some medicinal plants on fertility of albino rats. Indian J Pharmacol 1991, 23:253-257.

116. Gupta RS, Sharma R, Sharma A, Bhatnager AK, Dobhal MP, Joshi YC, Sharma MC: Effect of Alstonia scholaris bark extract on testicular function of Wistar rats. Asian J Androl 2002, 4:175-178.

117. Gupta RS, Bhatnager AK, Joshi YC, Sharma MC, Khushalani V, Kachhawa JBS: Induction of antifertility with lupeol acetate in male albino rats. Pharmacology 2005, 75:57-62.

118. Hilou A, Nacoulma OG, Guiguemde TR: In vivo antimalarial activities of extracts from Amaranthus spinosus L. and Boerhaavia erecta L. in mice. J Ethnopharmacol 2006, 103:236-240.

119. Timsina G: Evaluation of antimicrobial activities of some medicinal plants used in traditional medicine in Nepal, M.Sc. Thesis. Kirtipur, Nepal: Central Department of Botany, Tribhuvan University; 2003.

120. Chiu N, Chang K: The Illustrated Medicinal Plants in Taiwan, Volume 1. Taiwan: SMC publication Inc.; 1995.

121. Rashid S, Rather MA, Shah WA, Bhat BA: Chemical composition, antimicrobial, cytotoxic and antioxidant activities of the essential oil of Artemisia indica Willd. Food Chem 2013, 138:693-700.

122. Parajuli S: Medicinal Plants used in cuts and wounds in Kaski district Western Nepal) and their antimicrobial activities, M.Sc. Thesis. Kirtipur, Nepal: Central Department of Botany, Tribhuvan University; 2001.

123. Baliga MS, Shivashankara AR, Haniadka R, Dsouza J, Bhat HP: Phytochemistry, nutritional and pharmacological properties of Artocarpus heterophyllus Lam (jackfruit): A review. Food Res Int 2011, 44:1800-1811.

124. Sabnis PB, Gaitonde BB, Jetmalani M: Effects of alcoholic extracts of Asparagus racemosus on mammary glands of rats. Indian J Exp Biol 1968, 6:55-57

125. Pandey SK, Sahay A, Pandey RS, Tripathi YB: Effect of Asparagus racemosus rhizome (Shatavari) on mammary gland and genital organs of pregnant rat. Phytother Res PTR 2005, 19:721-724.

126. Joglekar GV, Ahuja RH, Balwani JH: Galactagogue effect of Asparagus racemosus. Indian Med J 1967, 61:165.

127. Gewali MB, Awale S: Aspects of Traditional Medicine in Nepal. Japan: Institute of Natural Medicine. University of Toyama; 2008.

128. Bhowmik D, Yadav JC, Tripathi KK, Kumar KPS: Herbal remedies of Azadirachta indica and its medicinal application. J Chem Pharm Res 2010 2:62-72.

129. Pokhrel NR, Adhikari RP, Baral MP: In-vitro evaluation of the antimicrobial activity of Bauhinia variegata, locally known as koiralo. World J Microbiol Biotechnol 2002, 18:69-71.

130. Sharma C, Aneja KR, Kasera R: Screening of Berberis aristata DC. for antimicrobial potential against the pathogens causing ear infection. Int J Pharmacol 2011, 7:536-541.

131. Bhattarai S: Ethnobotany and antimicrobial activities of selected medicinal plants of Nepal Himalaya, Ph.D. Thesis. Kirtipur, Nepal: Central Department of Botany, Tribhuvan University; 2009.

132. Bhattarai S, Chaudhary RP, Taylor RS: Ethnomedicinal plants used by the people of Manang district, central Nepal. J Ethnobiol Ethnomedicine 2006, 2:41.

133. Mahato RB: Diversity, use and conservation of plants in Palpa district, Nepal, Ph.D. Thesis. Kirtipur, Nepal: Central Department of Botany, Tribhuvan University; 2006

134. Shrestha MP: Medicinal plants used by local communities of Tokha (Chandeshwari) area and antimicrobial activities of some selected plants, M.Sc. Thesis. Kirtipur, Nepal: Central Department of Botany, Tribhuvan University; 2004

135. Yang XM, Wang ZK, Wang ZH, Li RX: Analysis of nutritive components and mineral element of Bergenae pacumbis inTibet. J Chang Veg 2009, 22:57-58.

136. Zhang Y, Liao C, Li J, Liu X: A review on resource status, bioactive ingredients, clinical applications and biological progress in Bergenia. J Med Plants Res 2011, 5:4396-4399.

137. Huang KC: The Pharmacology of Chinese Herbs. 2nd edition. New York, USA: CRC Press; 1999

138. Pertwee RG: Cannabinoids and the gastrointestinal tract. Gut 2001, 48:859-867.
139. Spadaro F, Costa R, Circosta C, Occhiuto F: Volatile composition and biological activity of key lime Citrus aurantifolia essential oil. Nat Prod Commun 2012, 7:1523-1526.

140. Zhou J, Xie G, Yan Z: Encyclopedia of Traditional Chinese Medicines: Molecular Structures, Pharmacological Activities, Natural Sources and Applications - Indexes. Volume 3, 5. Springer; 2011

141. Mukherjee PK, Nema NK, Maity N, Sarkar BK: Phytochemical and therapeutic potential of cucumber. Fitoterapia 2013, 84:227-236.

142. Jananie RK, Priya V, Vijayalashmi K: Determination of bioactive components of Cynodon dactylon by GC-MS analysis. N Y Sci J 2011 4:16-20.

143. Garg VK, Paliwal SK: Anti-Inflammatory activity of aqueous extract of Cynodon dactylon. Int J Pharmacol 2011, 7:370-375.

144. Ma K-J, Zhu Z-Z, Yu C-H, Zhang H, Liu J, Qin L-P: Analgesic, antiinflammatory, and antipyretic activities of the ethanol extract from Desmodium caudatum. Pharm Biol 2011, 49:403-407.

145. Wei $Y$, Zhang K, Zhang G, Ito Y: Isolation of five bioactive components from Eupatorium adenophorum Spreng using stepwise elution by high-speed counter-current chromatography. J Liq Chromatogr Relat Technol 2011, 34:2505-2515.

146. Vijaya K, Ananthan S, Nalinib R: Antibacterial effect of theaflavin, polyphenon 60 (Camelliasinensis) and Euphorbia hirta on Shigella spp. - a cell culture study. J Ethnopharmacol 1995, 49:115-118.

147. Jackson C, Agboke A, Nwoke V: In vitro evaluation of antimicrobial activity of combinations of nystatin and Euphorbia hirta leaf extract against Candida albicans by the checkerboard method. J Med Plants Res 2009, 3:666-669.

148. Lanhers MC, Fleurentin J, Dorfman P, Mortier F, Pelt JM: Analgesic, antipyretic and antiinflammatory properties of Euphorbia hirta. Planta Med 1991, 57:225-231.

149. Martinez V, Mariano A, Teresa OR, Lazcano ME, Bye R: Anti-inflammatory active compounds from the n-hexane extract of Euphorbia hirta. J Mex Chem Soc 1999, 43:103-105.

150. Sreelekshmi R, Latha PG, Arafat MM, Shyamal S, Shine VJ, Anuja GI, Suja SR, Rajasekharan S: Anti-inflammatory, analgesic and anti-lipid peroxidation studies on stem bark of Ficus religiosa Linn. Nat Prod Radiance 2007, 6:377-381.

151. Viswanathan S, Thirugnanasambantham P, Reddy MK, Narasimhan S, Subramaniam GA: Anti-inflammatory and mast cell protective effect of Ficus religiosa. Anc Sci Life 1990, 10:122-125.

152. Jung HW, Son HY, Minh CV, Kim YH, Park YK: Methanol extract of Ficus leaf inhibits the production of nitric oxide and proinflammatory cytokines in LPS-stimulated microglia via the MAPK pathway. Phytother Res 2008 22:1064-1069.

153. Jatav VS, Singh S, Khatri $P$, Sharma A: Recent pharmacological trends of Glycyrrhiza glabra Linn. Unani Res 2011, 1:1-11.

154. Igbinsosa OO, Igbinosa EO, Aiyegoro OA: Antimicrobial activity and phytochemical screening of stem bark extracts from Jatropha curcas (Linn). Afr J Pharm Pharmacol 2009, 3:058-062.

155. Erdemoglu N, Küpeli E, Yeşilada E: Anti-inflammatory and antinociceptive activity assessment of plants used as remedy in Turkish folk medicine. J Ethnopharmacol 2003, 89:123-129.

156. Talapatra SK, Karmacharya B, De SC: ( - )-Regiolone, an a-tetralone from Juglans regia: structure, stereochemistry and conformation. Phytochem Anal 1988, 27:3929-3932

157. Babula P, Adam V, Havel L, Kizek R: Naphthoquinones and their pharmacological properties. Ceská Slov Farm 2007, 56:114-120.

158. Claeson UP, Malmfors T, Wikman G, Bruhn JG: Adhatoda vasica: a critical review of ethnopharmacological and toxicological data. J Ethnopharmacol 2000, 72:1-20.

159. Jain VC, Shah DP, Sonani NG, Dhakara S, Patel NM: Pharmacognostical and preliminary phytochemical investigation of Lawsonia inermis L. leaf Romanian J Biol-Plant Biol 2010, 55:127-133.

160. Comai S, Dall'Acqua S, Grillo A, Castagliuolo I, Gurung K, Innocenti G: Essential oil of Lindera neesiana fruit: Chemical analysis and its potentia use in topical applications. Fitoterapia 2010, 81:11-16.

161. Orhan I, Küpeli E, Şener B, Yesilada E: Appraisal of anti-inflammatory potential of the clubmoss, Lycopodium clavatum L. J Ethnopharmacol 2007, 109:146-150.

162. Perry LM, Metzger J: Medicinal Plants of East and Southeast Asia: Attributed Properties and Uses. London: MIT Press; 1980 
163. Panthi MP, Chaudhary RP: Antibacterial acitivity of some selected foklore medicinal plants fom west Nepal. Sci World 2006, 4:16-21.

164. Thakur SC, Thakur SS, Chaube SK, Singh SP: An etheral extract of Kamala (Mallotus philippinensis (Moll.Arg) Lam.) seed induce adverse effects on reproductive parameters of female rats. Reprod Toxicol 2005, 20:149-156.

165. Lewis DA, Fields WN, Shaw GP: A natural flavonoid present in unripe plantain banana pulp (Musa sapientum L. var. paradisiaca) protects the gastric mucosa from aspirin-induced erosions. J Ethnopharmacol 1999, 65:283-288

166. Alisi CS, Nwanyanwu CE, Akujobi CO, Ibegbulem CO: Inhibition of dehydrogenase activity in pathogenic bacteria isolates by aqueous extracts of Musa paradisiaca (var sapientum). Afr J Biotechnol 2008, 7:1684-5315.

167. Rao VS, Rao A, Karanth KS: Anticonvulsant and neurotoxicity profile of Nardostachys jatamansi in rats. J Ethnopharmacol 2005, 102:351-356.

168. Vinutha B, Prashanth D, Salma K, Sreeja SL, Pratiti D, Padmaja R, Radhika S, Amit A, Venkateshwarlu K, Deepak M: Screening of selected Indian medicinal plants for acetylcholinesterase inhibitory activity. $J$ Ethnopharmacol 2007, 109:359-363.

169. Agrawal J, Pal A: Nyctanthes arbor-tristis Linn-A critical ethnopharmacological review. J Ethnopharmacol 2013, 146:645-658.

170. Raghavendra MP, Satish S, Raveesha KA: Phytochemical analysis and antibacterial activity of Oxalis corniculata; a known medicinal plant. mySCIENCE 2006, 1:72-78.

171. Matsuda H, Pongpiriyadacha Y, Morikawa T, Kishi A, Kataoka S, Yoshikawa M: Protective effects of steroid saponins from Paris polyphylla var. yunnanensis on ethanol- or indomethacin-induced gastric mucosal lesions in rats: structural requirement for activity and mode of action. Bioorg Med Chem Lett 2003, 13:1101-1106.

172. Liu X, Cui C, Zhao M, Wang J, Luo W, Yang B, Jiang Y: Identification of phenolics in the fruit of emblica (Phyllanthus emblica L.) and their antioxidant activities. Food Chem 2008, 109:909-915.

173. Duke JA: CRC Handbook of Medicinal Herbs. Boca Raton, FL: CRC Press; 1985.

174. Tomczyk M, Latté KP: Potentilla-A review of its phytochemical and pharmacological profile. J Ethnopharmacol 2009, 122:184-204.

175. Olajide O, Awe S, Makinde J: Pharmacological studies on the leaf of Psidium guajava. Fitoterapia 1999, 70:25-31.

176. Zhang WJ, Chen BT, Wang CY, Zhu QH, Mo Z: Mechanism of quercetin as an antidiarrheal agent. Yi Jun Yi Xue Xue Bao 2003, 23:1029-1031.

177. Coutino RR, Hernandez CP, Giles RH: Lectins in fruits having gastrointestinal activity: their participation in the hemagglutinating property of Escherichia coli 0157:H7. Arch Med Res 2001, 32:251-257.

178. Matsuura Y, Miyaichi Y, Tomimori T: Studies on the Nepalese crude drugs. XIX. On the flavonoid and phenylethanoid constituents of the root of Scutellaria repens Buch.-Ham. ex D. Don. Yakugaku Zasshi 1994, 114:775-788.

179. Bhargava S, Rao PS, Bhargava P, Shukla S: Antipyretic Potential of Swertia chirata Buch Ham. Root Extract. Sci Pharm 2009, 77:617-623.

180. Tita B, Bello U, Faccendini P, Bartolini R, Bolle P: Taraxacum officinale W.: pharmacological effect of ethanol extract. Pharmacol Res 1993, 27:23-24

181. Nisar M, Khan I, Ahmad B, Ali I, Ahmad W, Choudhary MI: Antifungal and antibacterial activities of Taxus wallichiana Zucc. J Enzyme Inhib Med Chem 2008, 23:256-260.

182. Sah S, Shrestha R, Koirala S, Bhattarai K: Phytochemical and antimicrobial assessment of five medicinal plants found in Terai region. Nepal J Sci Technol 2013, 13:79-86.

183. Chandramu C, Manohar RD, Krupadanam DGL, Dashavantha RV: Isolation, characterization and biological activity of betulinic acid and ursolic acid from Vitex negundo L. Phytother Res 2003, 17:129-134.
184. Dharmasiri M, Jayakody JRA, Galhena G, Liyanage SS, Ratnasooriya W: Anti-inflammatory and analgesic activities of mature fresh leaves of Vitex negundo. J Ethnopharmacol 2003, 87:199-206.

185. Kaur R, Kaur $\mathrm{H}$ : The Antimicrobial activity of essential oil and plant extracts of Woodfordia fruticosa. Arch App/ Sci Res 2010, 2:302-309.

186. Bhattarai S, Bhuju DR: Antimicrobial Activity of Useful Parts of Woodfordia fruticosa (Linn.) Kurz. of Nepal. Int J Pharm Biol Arch 2011, 2:756-761.

doi:10.1186/1746-4269-10-5

Cite this article as: Luitel et al:: Medicinal plants used by the Tamang community in the Makawanpur district of central Nepal. Journal of Ethnobiology and Ethnomedicine 2014 10:5.

\section{Submit your next manuscript to BioMed Central and take full advantage of:}

- Convenient online submission

- Thorough peer review

- No space constraints or color figure charges

- Immediate publication on acceptance

- Inclusion in PubMed, CAS, Scopus and Google Scholar

- Research which is freely available for redistribution

Submit your manuscript at www.biomedcentral.com/submit
C Biomed Central 